Japan. J. Med. Sci. Biol., 18, 227-238, 1965

\title{
VARIABILITY OF STRAINS OF JAPANESE ENCEPHALITIS VIRUS IN REGARD TO THE PH-DEPENDENCY IN HEMAGGLUTINATION*
}

\author{
TAKEShI OKUNO, MAKoto SUZUKI, AKIRA KONDO \\ AND TOSHIKO ITO \\ Department of Virology and Rickettsiology, National Institute of Health, Tokyo
}

(Received: September 9th, 1965)

\begin{abstract}
One hundred and twelve strains of Japanese encephaltis virus (JEV) isolated in Japan during the past 25 years were tested for hemagglutination (HA) with the suckling mouse brain antigen. In the pattern HA tests of a checkerboard system employing graded $\mathrm{pH}$, most of the strains showed about equal titers in the $\mathrm{pH}$ range of 6.0 to 7.0 , the maximum titers being obtained usually at $\mathrm{pH}$ 6.8. In contrast, 7 strains which had received more frequent passages than the rest indicated a different pattern in which the HA titers at the neutral $\mathrm{pH}$ were much lower than those at the acid $\mathrm{pH}$, resulting in demonstration of the peak titers at $\mathrm{pH} 6.2$ to 6.4. Analyses of the phenomenon have suggested, however, that the pH-dependency of JEV HA is a genetically stable property, being characteristic to each strain. It is highly probable that the $\mathrm{pH}$-dependency of JEV HA may be an expression of the physicochemical properties of the virus particle which control its adsorbing action onto red cells.
\end{abstract}

\section{INTRODUCTION}

The arbovirus HA has the tendency of pH-dependency (Sabin and Buescher, 1950 ; Chanock and Sabin, 1953, 1954a, 1954b; Sweet and Sabin, 1954). The HA with the antigen prepared by the method of Clarke and Casals (1958) from suckling mouse brains infected with Nakayama-NIH strain of JEV and goose red cells shows the highest titer at $\mathrm{pH} 6.4$ than at any other $\mathrm{pH}$ between 6.0 and 7.0.

In 1958, Oya (Unpublished) noted that antigens from 2 freshly isolated JEV strains showed a higher $\mathrm{HA}$ titer at $\mathrm{pH} 6.8$ than at $\mathrm{pH}$ 6.4. Since a good number of JEV strains isolated in this or other laboratories during the last 25 years were available, attempts were made to observe variability among these strains in the $\mathrm{pH}$-dependency employing the pattern HA test. A limited trial was also made to test the genetical stability of this property.

\section{MATERIALS AND METHODS}

Viruses: A total of 112 strains including sublines were subjected to the present study. The name or number and history of each strain are illustrated in Tables 1 and 2. Strains H-58 and I-58 were isolated by Ohtahara et al. (1959). Strains Konishi,

* Aided in part by Grant RF-58064 and Grant RF-60232 supplied to this institute from the Rockefeller Foundation, U. S. A.

.奥野剛・鈴木誠・近藤昭・伊東寿子（国立予防衛生研究所ウイルス・リケッチア部） 
Okamoto and Yamashita were kindly given by Dr. Kono of the Kyoto University. Most of the other strains have been maintained in this department.

Source of antigen: All of the strains were passed at least once in the suckling mouse brain. The inoculum at each passage was a $10^{-2}$ to $10^{-3}$ diluted suspension of the preceding passage material made in phosphate buffered saline supplemented with $2 \%$ antibody-free calf serum. After harvest, the brains were kept in a dry ice cabinet until processing.

Preparation of antigen: The antigens were prepared by acetone-ether (AE) or sucroseacetone (SA) extraction. A crude alkaline aqueous antigen was also employed. Details of the techniques for antigen preparation appeared elsewhere (Clarke and Casals, 1958). The concentrations of infected suckling mouse brains in the AE, SA and crude antigens were 25,33 and $10 \%$, respectively. When necessary, the aritigen was lyophilized in ampules and stored at $-20^{\circ} \mathrm{C}$.

Red blood cells for HA: Except two of the present experiments, goose cells were employed. The stock goose cell suspension was prepared according to the technique of Clarke and Casals (1958) so as to show an optical density of 0.450 when diluted $1: 40$. The stock goose cell suspension made in dextrose-gelatin-veronal stored for less than 2 weeks was used by diluting $1: 24$ in the virus adjusting diluent (VAD). The one-dayold chick red cells were prepared and used in the same manner.

The antigen diluent, egg albumin borate saline (EA): For an economical reason, egg albumin soluble (Difco) was substituted for bovine albumin recommended earlier (Clarke and Casals, 1958). Egg albumin, initially employed by Oya (1958, unpublished) gives HA patterns comparable to bovine plasma albumin. Usually, a stock egg albumin solution (stock EA) was prepared with a mortar and pestle at $4 \%$. The turbid suspension was kept in a refrigerator after $\mathrm{pH}$ adjustment. Before use, the stcck EA was shaken vigourously, and centrifuged at 3,000 rpm for 7 minutes. The supernatant was mixed with 9 volumes of borate-buffered saline of $\mathrm{pH} 9.0$. It was used within 3 days after dilution.

Procedures for HA tests: HA tests were performed by the method of Clarke and Casals (1958). The freeze-dried antigen was reconstituted shortly before test and diluted $1: 200$. Then serial two-fold dilutions in EA were made in test tubes up to $1: 51,200$. Each dilution of the antigen was distributed into depressions of a lucite tray in the amount of $0.4 \mathrm{ml}$, to which was added an equal volume of a goose or one-day-chick red cell suspension in VAD, $\mathrm{pH} 6.0-7.0$. A $2 \mathrm{ml}$ or Cornwall pipette was used to add the cell suspension. The tray was allowed to stand in an incubator at $37^{\circ} \mathrm{C}$ for an hour. An inevitable fluctuation of electrically measured $\mathrm{pH}$ at the HA test was within 0.03 .

Criteria for reading: The reciprocal of the highest dilution of an antigen giving a partial or complete agglutination was taken as the endpoint. When HA titers at different $\mathrm{pH}$ were identical, the optimum $\mathrm{pH}$ for the antigen was expressed by the highest $\mathrm{pH}$ giving the highest titer.

\section{RESULTS}

The pH-dependency in HA of 68 JEV Strains Isolated in 1961:

Table 1 shows the results of HA tests with SA antigen prepared from suckling mouse brains infected with each isolate in 1961 (Oya et al, unpublished). Most of the HA test were repeated twicd or more with the result of giving identical HA patterns. The infected suckling mouse brain was used exclusively as the antigen source. 
Although the HA titers of each strain varied from $1: 3,200$ to $1: 51,200$, the optimum $\mathrm{pH}$ was always around 6.8. None of the strains showed the highest HA titer at a $\mathrm{pH}$ lower than 6.6. The HA titers at $6.6,6.8$ and 7.0 were very close with each strain listed. All the strains appeared to be uniform with respect to the optimum $\mathrm{pH}$ for HA around 6.8, although they were isolated during a 2-month-period (Oya et al., unpublished).

The pH-dependency of HA Demonstrated with 44 JEV Strains Isolated during the Period of 1935-1960:

The $\mathrm{pH}$-dependency and the titers of HA tests with these 44 antigens are presented in Table 2. A total of 8 antigens possessed the optimum $\mathrm{pH}$ either at 6.4 or at 6.2. Three of these were substrains of Nakayama and the remainders were strains Kalinina, 2869, G-1-Late, H-58 and I-58. The other strains showed the optimum $\mathrm{pH}$ around 6.8.

In Table 3, HA patterns of $10 \mathrm{JEV}$ strains are compared. Strains Nakayama-NIH and I-58 differ not only in the optimum $\mathrm{pH}$ but also in the shape of the pattern from the strains given in the right half of the table. The HA pattern of JaGAr $\$ 01$ strain is flat between $\mathrm{pH} 6.4$ and 7.0. On the other hand, the HA titer of Nakayama-NIH antigen was $1: 12,800$ at its optimum $\mathrm{pH}(6.4)$, 16-fold higher than that at $\mathrm{pH} 7.0$. An extremely sharp pH-dependency was observed with I-58 strain showing as high a titer as $1: 6,400$ at $\mathrm{pH} 6.2$, whereas at $\mathrm{pH} 7.0$ no agglutination occurred even at $1: 200$.

Inability of Mouse Brain Passage to Modify the Characteristics of the pH-dependency of JEV Strains.

A question arose as to whether the successive passages of a strain through the adult mouse brain have brought the optimum $\mathrm{pH}$ of $\mathrm{HA}$ to a more acid side since none of the strains passed through the suckling mouse brain gave an optimum $\mathrm{pH}$ at 6.4 or 6.2 , whereas those which possessed an optimum $\mathrm{pH}$ at 6.4 or 6.2 had been passed at least 20 times through adult mouse brains. As can be seen in Tables 2 and 4, G-1-Early strain which had been passed 7 times in the adult mouse brain showed an optimum $\mathrm{pH}$ at 6.8. On the other hand, G-1-Late strain undergoing 189 adult mouse brain passages gave an optimum $\mathrm{pH}$ at 6.4 , although there was no marked difference in the HA pattern. These tests were repeated more than 5 times giving consistent results.

One of the isolates in 1960, JaGAr 15460, was passed through the adult mouse brain to find whether its optimum pH would shift from 6.8 to 6.4. After every 20 passages, $\mathrm{AE}$ antigen was prepared from infected mouse brains. The results are given in Table 5 , in which no appreciable change of the optimum $\mathrm{pH}$ is shown.

Suckling mouse brain passages were carried out with strains which showed their optimum $\mathrm{pH}$ at 6.4 or 6.2 . As noted in Table 5 , the optimum $\mathrm{pH}$ of Nakayama-NIH and I-58 strains did not shift by the additional 12 or 16 suckling mouse brain passages.

The results indicated that the optimum $\mathrm{pH}$ of $\mathrm{HA}$ is characteristic to each strain, genetically stable and not influenced by passing the virus serially through the adult or suckling mouse brain in the stated manner.

The pH-dependency in HA of JE Viruses Obtained by Serial Limiting Dilution Passage or by Plaque Purification in Chick Embryo Cell Cultures:

Attempts were made to find whether the preparation of JEV strains in the preceding experiments were genetically homogeneous or not, since the $\mathrm{pH}$-dependency appeared to have been caused by a mixed population of two viruses which were distinct from each other in $\mathrm{pH}$-dependency. The $\mathrm{pH}$-dependency of the $\mathrm{AE}$ antigen prepared from suckling mouse brains infected with clone-purified viruses of each strain was tested. 
Table 1. pH-depency in HA of JEV strains which were isolated during the year of 1961 .

\begin{tabular}{|c|c|c|c|c|c|c|c|c|}
\hline \multirow{2}{*}{\multicolumn{3}{|c|}{ Strain Name }} & \multicolumn{4}{|c|}{ Isolation } & \multicolumn{2}{|c|}{$\mathrm{HA}^{* *}$} \\
\hline & & & \multicolumn{2}{|c|}{ Date } & \multirow{2}{*}{$\frac{\text { Source }}{\text { Mosq. }(\mathrm{CT})^{*}}$} & \multirow{2}{*}{$\frac{\text { Place }}{\text { Gunma-Akabane }}$} & \multirow{2}{*}{$\frac{\text { Titer }}{3,200}$} & \multirow{2}{*}{$\begin{array}{c}\begin{array}{c}\text { Highest } \\
\text { opt. } \mathrm{pH}\end{array} \\
6.6\end{array}$} \\
\hline 1 & JaGAr & 11161 & Aug. & 9 & & & & \\
\hline 2 & 11 & 11761 & July & 27 & " & Gunma-Itakura & 6,400 & 6.8 \\
\hline 3 & " & 12261 & $\prime \prime$ & 28 & " & Gunma-Kiryu & 3,200 & $6.8+* * *$ \\
\hline 4 & " & 12361 & $\prime \prime$ & 28 & " & 11 & 6,400 & 6.8 \\
\hline 5 & " & 14761 & Aug. & 4 & $\prime \prime$ & "I & 3,200 & 6.8 \\
\hline 6 & " & 14861 & $\prime \prime$ & 3 & $\prime \prime$ & Gunma-Itakura & 6,400 & 6.8 \\
\hline 7 & " & 16561 & " & 3 & "I & " & 3,200 & 6.6 \\
\hline 8 & " & 17861 & $\prime \prime$ & 9 & $\prime \prime$ & Gunma-Akabane & 6,400 & 6.8 \\
\hline 9 & "1 & 18161 & "1 & 9 & $\prime \prime$ & 11 & 6,400 & $6.8+$ \\
\hline 10 & " & 18361 & " & 9 & $\prime \prime$ & " & 6,400 & $6.8+$ \\
\hline 11 & " & 19061 & "1 & 10 & $\prime \prime$ & Gunma-Itakura & 3,200 & 7.0 \\
\hline 12 & " & 19161 & "1 & 9 & $\prime \prime$ & Gunma-Akabane & 3,200 & 6.8 \\
\hline 13 & "1 & 19361 & $\prime \prime$ & 9 & $\prime \prime$ & 11 & 6,400 & 6.6 \\
\hline 14 & " & 19461 & "1 & 10 & $\prime \prime$ & Gunma-Itakura & 6,400 & 6.8 \\
\hline 15 & " & 19661 & $\prime \prime$ & 11 & $\prime \prime$ & Gunma-Kiryu & 12,800 & 6.8 \\
\hline 16 & " & 20061 & $\prime \prime$ & 4 & $\prime \prime$ & $\prime \prime$ & 25,600 & 6.6 \\
\hline 17 & "1 & 20561 & July & 27 & "1 & Gunma-Itakura & 51,200 & 6.6 \\
\hline 18 & " & 20661 & Aug. & 18 & $\prime \prime$ & Gunma-Kiryu & 12,800 & 6.8 \\
\hline 19 & "1 & 21161 & $\prime \prime$ & 18 & "1 & $\prime \prime$ & 12,800 & 6.6 \\
\hline 20 & " & 21361 & $\prime \prime$ & 10 & $\prime \prime$ & Gunma-Itakura & 25,600 & 6.6 \\
\hline 21 & "1 & 21561 & July & 28 & $\prime \prime$ & Gunma-Kiryu & 12,800 & 6.8 \\
\hline 22 & " & 21761 & Aug. & 4 & " & "I & 12,800 & 6.8 \\
\hline 23 & " & 21861 & July & 28 & $\prime \prime$ & "1 & 3,200 & 6.6 \\
\hline 24 & " & 22361 & Aug. & 18 & " & $\prime \prime$ & 3,200 & 6.6 \\
\hline 25 & "1 & 23161 & $\prime \prime$ & 9 & $\prime \prime$ & Gunma-Akabane & 25,600 & 6.8 \\
\hline 26 & "1 & 23661 & " & 11 & $\prime \prime$ & Gunma-Kiryu & 25,600 & 6.6 \\
\hline 27 & " & 24161 & "1 & 16 & " & Gunma-Akabane & 25,600 & 6.8 \\
\hline 28 & "1 & 25861 & $\prime \prime$ & 17 & " & Gunma-Itakura & 25,600 & 6.8 \\
\hline 29 & "1 & 27061 & $\prime \prime$ & 17 & "1 & " & 6,400 & 6.8 \\
\hline 30 & " & 27361 & 11 & 4 & " & Gunma-Kiryu & 6,400 & 6.6 \\
\hline 31 & "1 & 27861 & July & 27 & $\prime \prime$ & Gunma-Itakura & 6,400 & 6.6 \\
\hline 32 & " & 28161 & Aug. & 18 & "1 & Gunma-Kiryu & 3,200 & 6.8 \\
\hline 33 & "1 & 28261 & $\prime \prime$ & 4 & " & "I & 3,200 & 6.6 \\
\hline 34 & "1 & 30761 & "1 & 10 & " & Gunma-Itakura & 6,400 & 6.6 \\
\hline 35 & "1 & 31861 & $\prime \prime$ & 4 & $\prime \prime$ & Gunma-Kiryu & 12,800 & 7.0 \\
\hline 36 & "1 & 32161 & " & 10 & $\prime \prime$ & Gunma-Itakura & 6,400 & 6.6 \\
\hline 37 & " & 32461 & July & 28 & $\prime \prime$ & Gunma-Kiryu & 12,800 & 6.6 \\
\hline 38 & "1 & 32861 & " & 27 & $\prime \prime$ & Gunma-Itakura & 6,400 & 6.6 \\
\hline 39 & $\prime \prime$ & 33461 & " & 21 & $\prime \prime$ & Gunma-Kiryu & 6,400 & 6.6 \\
\hline
\end{tabular}


Table 1. (continued)

\begin{tabular}{|c|c|c|c|c|c|c|c|c|}
\hline \multirow{2}{*}{\multicolumn{3}{|c|}{ Strain Name }} & \multicolumn{4}{|c|}{ Isolation } & \multicolumn{2}{|c|}{$\mathrm{HA}^{* *}$} \\
\hline & & & \multicolumn{2}{|c|}{ Date } & \multirow{2}{*}{$\frac{\text { Source }}{\text { Mosq. }(\mathrm{CT})}$} & \multirow{2}{*}{$\frac{\text { Place }}{\text { Gunma-Kiryu }}$} & \multirow{2}{*}{$\frac{\text { Titer }}{25,600}$} & \multirow{2}{*}{$\begin{array}{l}\begin{array}{l}\text { Highest } \\
\text { opt. pH }\end{array} \\
6.6\end{array}$} \\
\hline 40 & $\mathrm{JaGAr}$ & 33961 & Aug. & 11 & & & & \\
\hline 41 & 11 & 34061 & July & 21 & " & $\prime \prime$ & 12,800 & 6.6 \\
\hline 42 & "1 & 34961 & $\prime \prime$ & 28 & "I & "I & 12,800 & 6.8 \\
\hline 43 & "1 & 35461 & $\prime \prime$ & 27 & $\prime \prime$ & Gunma-Itakura & 25,600 & 6.8 \\
\hline 44 & "1 & 35661 & " & 26 & "1 & Gunma-Akabane & 25,600 & 6.8 \\
\hline 45 & "1 & 36161 & " & 27 & " & Gunma-Itakura & 6,400 & 6.6 \\
\hline 46 & "1 & 36261 & $\prime \prime$ & 12 & " & Gunma-Akabane & 3,200 & 6.6 \\
\hline 47 & "1 & 36961 & Aug. & 3 & " & Gunma-Itakura & 3,200 & 6.8 \\
\hline 48 & "I & 49561 & "I & 10 & " & " & 6,400 & 6.6 \\
\hline 49 & "1 & 49761 & " & 11 & " & Gunma-Kiryu & 12,800 & 6.8 \\
\hline 50 & " & 50161 & " & 30 & $\prime \prime$ & Gunma-Akabane & 6,400 & 6.8 \\
\hline 51 & "1 & 50261 & $\prime \prime$ & 30 & $\prime \prime$ & " & 25,600 & 6.6 \\
\hline 52 & "I & 51961 & Sept. & 1 & $\prime \prime$ & Gunma-Kiryu & 3,200 & 6.8 \\
\hline 53 & " & 52561 & $\prime \prime$ & 7 & $\prime \prime$ & Gunma-Itakura & 3,200 & 6.6 \\
\hline 54 & " & 54561 & $\prime \prime$ & 7 & $\prime \prime$ & " & 6,400 & 6.6 \\
\hline 55 & "1 & 58161 & Aug. & 4 & " & Gunma-Kiryu & 3,200 & 6.8 \\
\hline 56 & "1 & 58261 & $\prime \prime$ & 24 & " & Gunma-Itakura & 3,200 & 6.8 \\
\hline 57 & "I & 58461 & July & 28 & " & Gunma-Kiryu & 3,200 & 6.8 \\
\hline 58 & "1 & 58561 & " & 28 & " & " & 6,400 & 6.8 \\
\hline 59 & $\prime \prime$ & 60061 & "1 & 21 & $\prime \prime$ & " & 6,400 & 6.8 \\
\hline 60 & "1 & 60561 & "1 & 28 & " & " & 6,400 & 6.6 \\
\hline 61 & " & 60661 & $\prime \prime$ & 28 & " & " & 3,200 & 6.8 \\
\hline 62 & " & 60761 & Aug. & 4 & $\prime \prime$ & " & 25,600 & 6.6 \\
\hline 63 & " & 60961 & Sept. & 28 & " & Gunma-Itakura & 12,800 & 6.6 \\
\hline 64 & " & 61561 & July & 27 & $\prime \prime$ & 11 & 12,800 & 6.6 \\
\hline 65 & " & 72061 & Aug. & 4 & $\prime \prime$ & Gunma-Kiryu & 12,800 & 6.6 \\
\hline 66 & " & 72361 & July & 28 & " & " & 3,200 & 6.8 \\
\hline 67 & 'I & 101861 & Aug. & 18 & "I & $\prime \prime$ & 12,800 & 6.6 \\
\hline 68 & $\mathrm{JaTH}$ & 161 & & & Human brain & Tokyo & 12,800 & 6.8 \\
\hline
\end{tabular}

* Culex tritaeniorhyncus mosquito

** All antigens were prepared by SA methods with the third suckling mouse brain passage.

*** The HA was not performed at $\mathrm{pH}$ 7.0.

The JaGAr 15460 strain was purified by 5 successive limiting dilution passages through adult mouse brains. The $\mathrm{pH}$-dependency of the $\mathrm{AE}$ antigen thus prepared did not differ noticeably from that of the parent, as shown in Table 6, the optimum $\mathrm{pH}$ being 6.8.

Viruses plaque-purified in the chick embryo cells of I-58, JaGAr\#01, Nakayama-NIH and Nakayama-Yakken strains were given by Dr. Akira Oya of this laboratory. The antigens prepared with those plaque-purified viruses had the optimum $\mathrm{pH}$ identical to that possessed by their parent strains except Nakayama-NIH strain (Table 6). The parent strain showed the optimum $\mathrm{pH}$ at 6.4 ; the optimum $\mathrm{pH}$ for the plaque-purified Naka- 


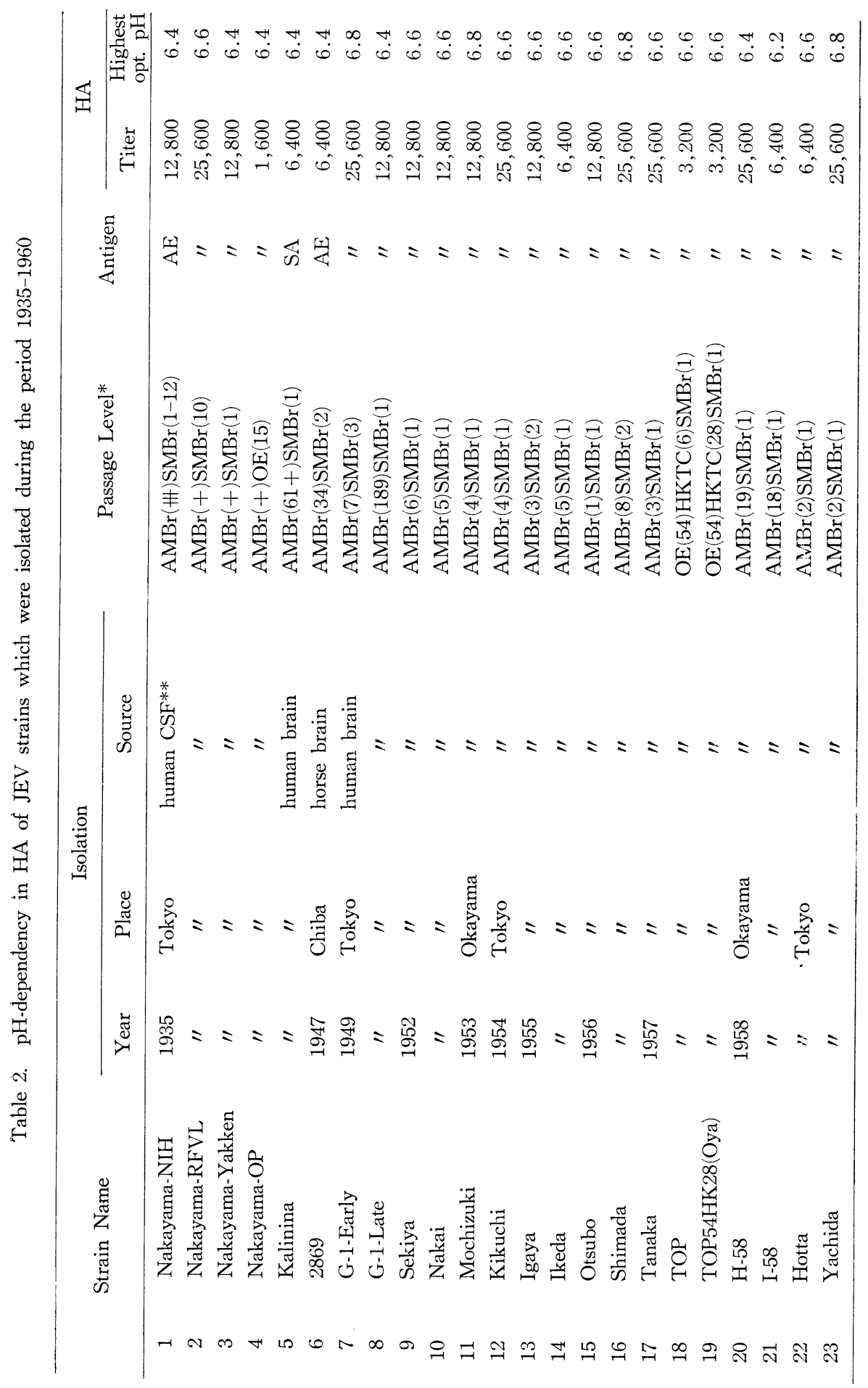




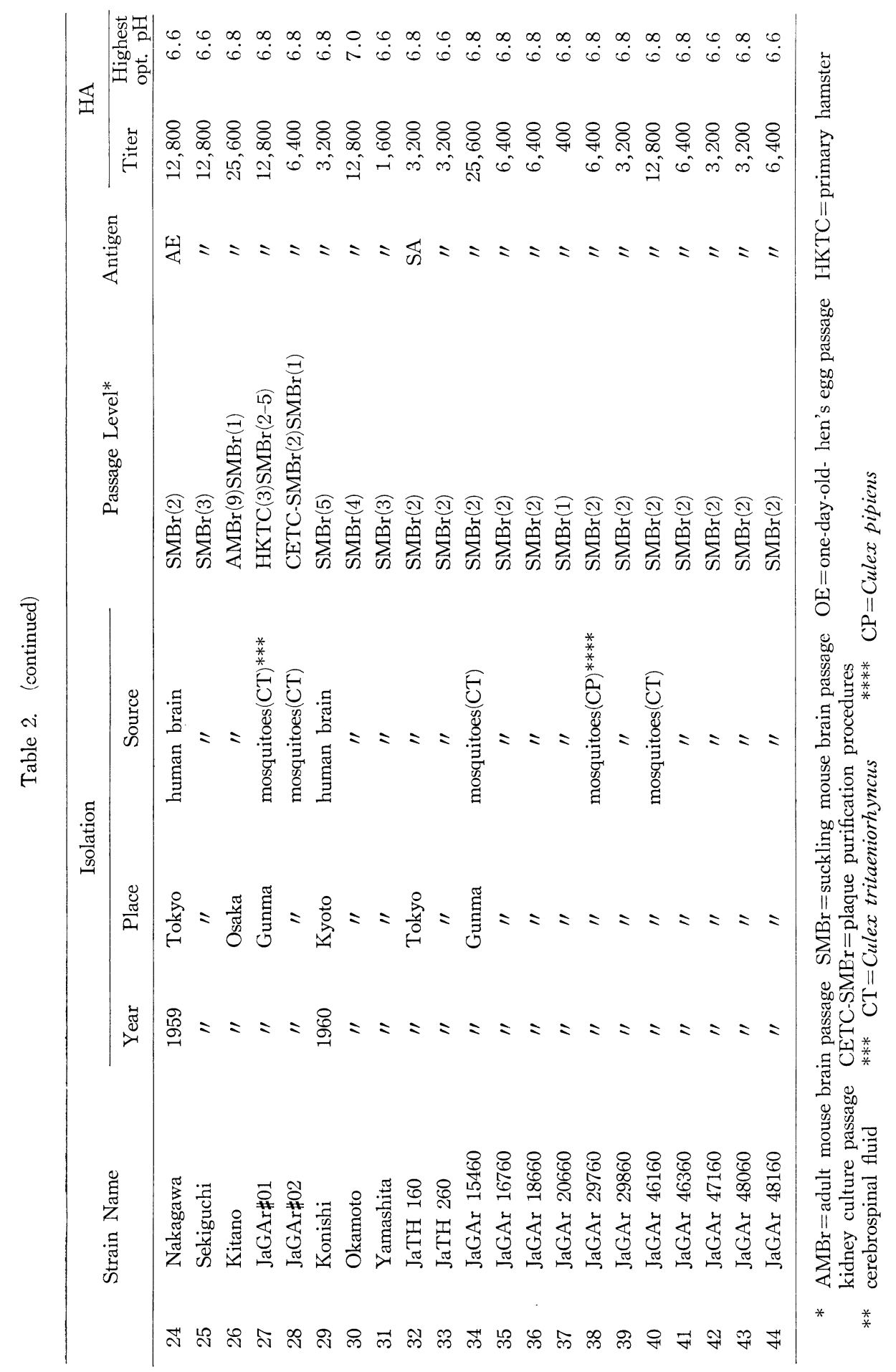


Table 3. A comparison of HA patterns given by $10 \mathrm{JEV}$ strains

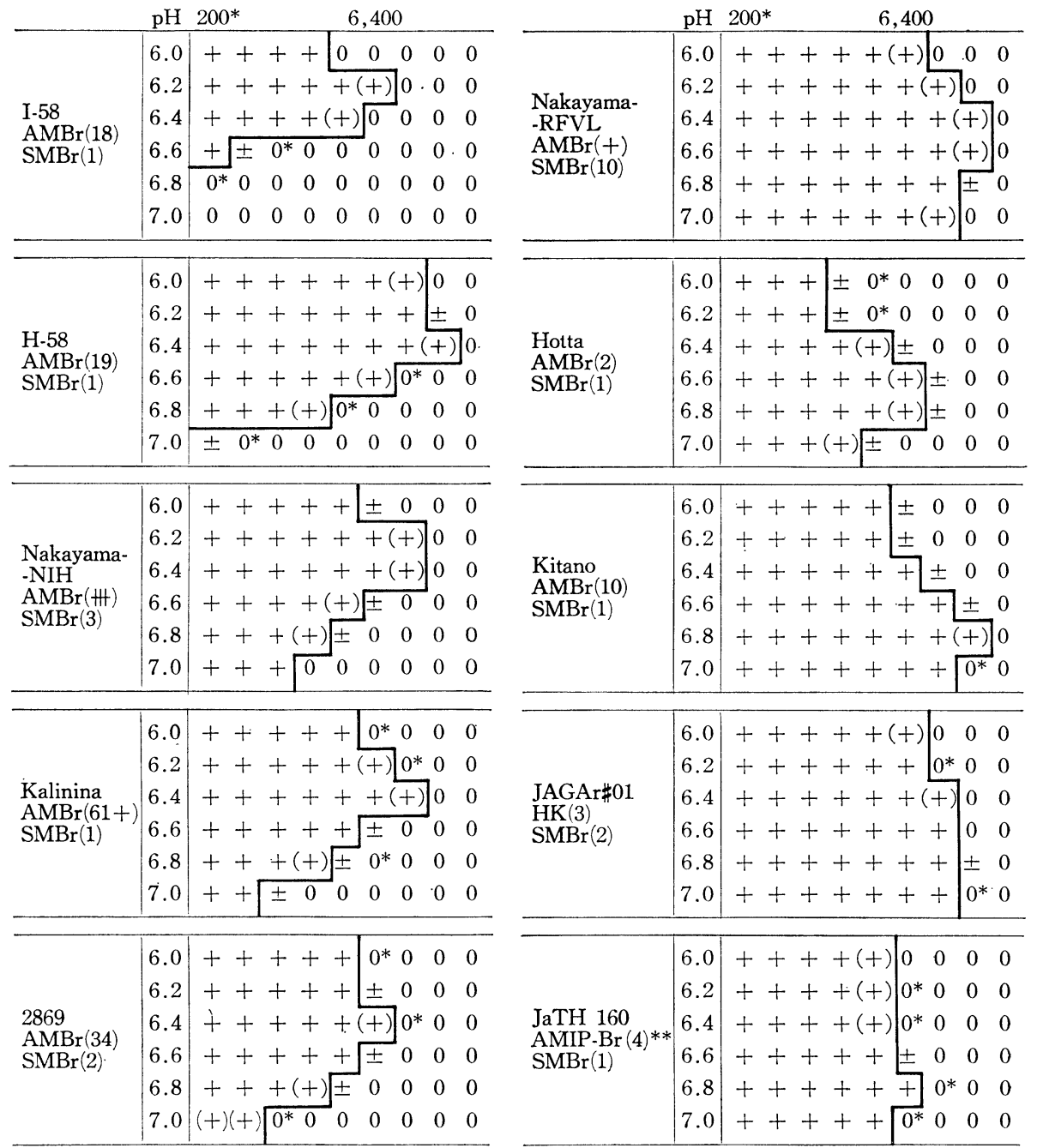

+ : Positive agglutination (t): Partial agglutination

$\pm:$ Trace agglutination $\quad 0^{*}:$ Almost negative $0:$ Negative

* Antigen dilution (1:)

** The passage by inoculating adult mouse i. p. and harvesting the brain of infected mouse.

yama-NIH strain was slightly more alkaline, i. e., 6.6. This was confirmed by repeated tests employing 2 lots of antigen.

Influence of Methods for Antigen Preparation and Different Red Cells upon pHdependency :

As mentioned previously, the antigen was extracted by either the $\mathrm{AE}$ or the SA method and all the tests were performed with goose cells. In order to ascertain whether the $\mathrm{pH}$-dependency of HA pattern is an intrinsic property of each virus or influenced by certain other factors, influences of the method of antigen preparation and of the 
Table 4. Comparison of pH-dependency in HA between G-1-Early and G-1-Late strains

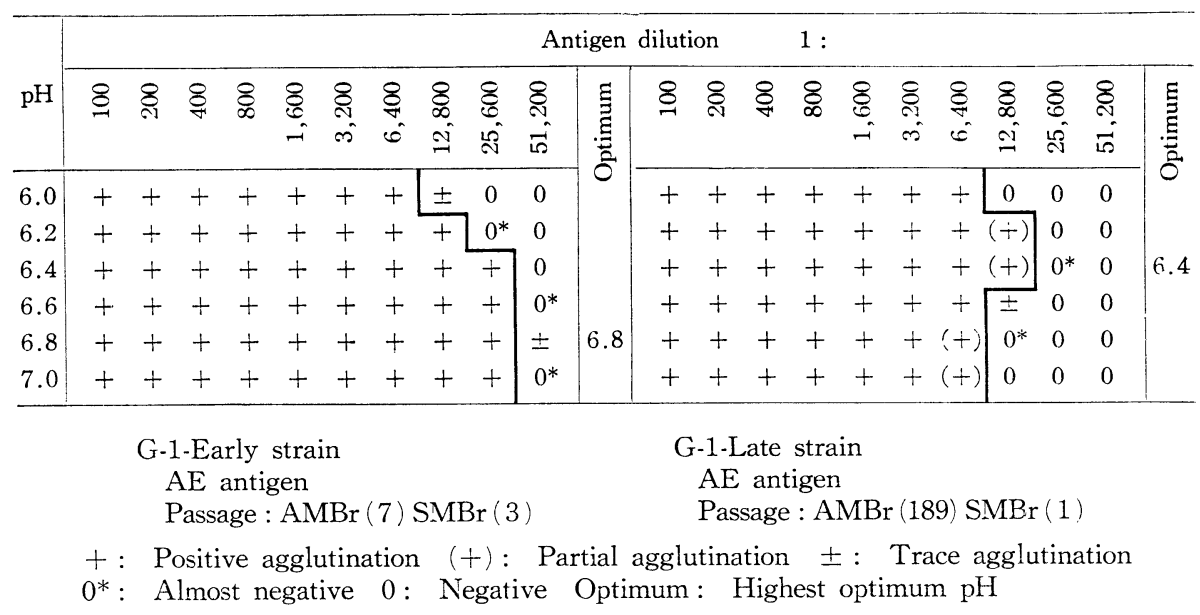

Table 5. Relationship between passage levels in mice and $\mathrm{pH}$-dependency of $\mathrm{HA}$ by $3 \mathrm{JEV}$ strains

\begin{tabular}{|c|c|c|c|c|}
\hline Strain Name & Passage Level & Antigen & HA titer & $\begin{array}{l}\text { Highest } \\
\text { Opt. pH }\end{array}$ \\
\hline \multirow[t]{7}{*}{ JaGAr 15460} & $\operatorname{SMBr}(2)$ & S A & 25600 & 6.8 \\
\hline & $\operatorname{SMBr}(2) \operatorname{AMBr}(20) \operatorname{SMBr}(1)$ & $\mathrm{AE}$ & 12800 & 6.8 \\
\hline & $\operatorname{SMBr}(2) \operatorname{AMBr}(40) \operatorname{SMBr}(1)$ & $\mathrm{AE}$ & 25600 & 6.8 \\
\hline & $\operatorname{SMBr}(2) \mathrm{AMBr}(59) \operatorname{SMBr}(1)$ & $\mathrm{AE}$ & 3200 & 6.8 \\
\hline & $\operatorname{SMBr}(2) \operatorname{AMBr}(65) \operatorname{SMBr}(1)$ & $\mathrm{AE}$ & 6400 & 6.6 \\
\hline & $\mathrm{SMBr}(2) \operatorname{AMBr}(80) \operatorname{SMBr}(1)$ & $\mathrm{AE}$ & 6400 & 6.8 \\
\hline & $\operatorname{SMBr}(2) \operatorname{AMBr}(100) \operatorname{SMBr}(1)$ & $\mathrm{AE}$ & 12800 & 6.6 \\
\hline \multirow[t]{2}{*}{ Nakayama-NIH } & $\mathrm{AMBr}(\mathrm{m}) \mathrm{SMBr}(3)$ & $\mathrm{AE}$ & 12800 & 6.4 \\
\hline & $\mathrm{AMBr}(\mathrm{H}) \mathrm{SMBr}(12)$ & $\mathrm{AE}$ & 12800 & 6.4 \\
\hline \multirow[t]{2}{*}{$\mathrm{I}-58$} & $\operatorname{AMBr}(18) \operatorname{SMBr}(1)$ & $\mathrm{AE}$ & 6400 & 6.2 \\
\hline & $\mathrm{AMBr}(18) \operatorname{SMBr}(16)$ & $\mathrm{AE}$ & 3200 & 6.2 \\
\hline
\end{tabular}

species of red cells were checked.

Several litters of suckling mice were infected with a $10^{-2}$ dilution of the stock lyophilized virus of I-58 or JaGAr\#01 strain and the brains were harvested 3 days after inoculation. A batch of the infected suckling mouse brains was divided into 3 parts from which 1) crude alkaline aqueous, 2) $\mathrm{AE}$ and 3) SA antigens were prepared. They were tested simultaneously with goose and 1-day-chick cells. The results are illustrated in Table 7.

Although HA titers given by 1-day-chick red cells appeared to be uniformly lower than those by goose cells as reported earlier (Porterfield, 1957) and the HA at a relatively alkaline $\mathrm{pH}$ with crude antigen tended to be weak, the $\mathrm{pH}$-dependency of each strain was not materially altered by the method of antigen preparation or by the species 
Table 6. pH-dependency of the antigens prepared from single virus derived clone of each JEV strain in comparison with those of parental virus

\begin{tabular}{|c|c|c|c|c|}
\hline Strain Name & Passage Level & Antigen & $\begin{array}{l}\mathrm{HA} \\
\text { titer }\end{array}$ & $\begin{array}{l}\text { Highest } \\
\text { Opt. pH }\end{array}$ \\
\hline JaGAr 15460 & $\operatorname{SMBr}(2) \operatorname{AMBr}(14) \operatorname{SMBr}(1)$ & A E & 6400 & 6.8 \\
\hline \multirow{3}{*}{ JaGAr $\# 02$} & $\operatorname{SMBr}(2) \operatorname{AMBr}(15) \operatorname{AMBrLDP} *(5) \operatorname{SMBr}(1)$ & $\mathrm{AE}$ & 3200 & 6.8 \\
\hline & $\operatorname{SMBr}(7)$ & $\mathrm{AE}$ & 3200 & 6.8 \\
\hline & CETC-SMBr** (2) SMBr (1) & $\mathrm{AE}$ & 6400 & 6.8 \\
\hline \multirow[t]{2}{*}{ I-58 } & $\operatorname{AMBr}(18) \operatorname{SMBr}(1)$ & $\mathrm{AE}$ & 6400 & 6.2 \\
\hline & $\operatorname{AMBr}(18)$ CETC-SMBr $(3)^{* *} \operatorname{SMBr}(2)$ & $\mathrm{AE}$ & 6400 & 6.2 \\
\hline \multirow[t]{2}{*}{ Nakayama-NIH } & $\mathrm{AMBr}(\mathrm{H}) \mathrm{SMBr}(5)$ & $\mathrm{AE}$ & 12800 & 6.4 \\
\hline & $\mathrm{AMBr}(+\#) \operatorname{SMBr}(5)$ CETC-SMBr $(3)^{* *} \operatorname{SMBr}(4)$ & $\mathrm{AE}$ & 6400 & 6.6 \\
\hline \multirow{2}{*}{$\begin{array}{l}\text { Nakayama- } \\
\text {-Yakken }\end{array}$} & $\mathrm{AMBr}(H) \operatorname{SMBr}(1)$ & $\mathrm{AE}$ & 12800 & 6.4 \\
\hline & $\operatorname{AMBr}(+) \operatorname{SMBr}(1)$ CETC-SMBr (1)** $\operatorname{SMBr}(2)$ & $\mathrm{AE}$ & 12800 & 6.4 \\
\hline
\end{tabular}

* A limiting dilution passage through adult mouse brain.

** Plaque purification of the viruses in chick embryo tissue culture.

of red cells used. This finding constituted further evidence that the phenomenon of $\mathrm{pH}$ dependency is due to an intrinsic property of each strain of JEV.

\section{DISCUSSION}

The present paper deals, for the first time, with the strain variation of $\mathrm{JEV}$ in $\mathrm{pH}$ dependency of HA. Tests with more than $100 \mathrm{JEV}$ strains have demonstrated that a certain number of strains differ in HA characteristics from fresh isolates. Strains Nakayama-NIH, Nakayama-Yakken, Kalinina, 2869, G-1-Late, H-58 and I-58 displayed similar HA characteristics as the laboratory-passed strains. The optimum $\mathrm{pH}$ for $\mathrm{HA}$ of those strains was 6.4 or lower. No fresh strain possessed the optimum $\mathrm{pH}$ at 6.4 or lower. Accordingly, the optimum $\mathrm{pH}$ for JEV HA lies between 6.6 and 7.0 with a strain isolated freshly by an intracerebral inoculation of suckling mice.

Comparatively acid optimum $\mathrm{pH}$, characteristic to some laboratory-passed strains may have been caused by certain factors operative in successive passages. The adult mouse brain tissue may have selected such strains, although the experimental passage of JaGAr 15460 strain through adult mouse brains provides no evidence supporting the above hypothesis.

Investigation was made to find whether the HA characteristics furnish a good tool for the genetic study of JEV as a marker. This question should be answered by "yes" because 1) the HA characteristics did not distinguish goose cells from those of 1-daychick, 2) the difference in the method of antigen preparation did not influence the HA characteristics, 3) the property remained unaltered during 100 adult mouse brain passages and 4) this was also true with clonized viruses.

An exception was encountered with Nakayama-NIH strain. Umclonized Nakayama-NIH strain consistently showed the optimum $\mathrm{pH}$ at 6.4 , whereas the clonized strain at 6.6. Although the difference was merely 0.2 , this was not likely to have been caused by technical errors, because of the high reproducibility of the result. By the plaque purification performed in exactly the same manner, I-58 strain failed to shift its optimum $\mathrm{pH}$ for HA. An explanation for these phenomena would be possible only by analysing 
Table 7. Inability to influence the optimum $\mathrm{pH}$ in HA of two JEV strains by changing the methods of antigen preparation and cells

\begin{tabular}{|c|c|c|c|c|c|c|c|c|c|c|c|c|c|c|c|c|c|}
\hline & $\mathrm{pH}$ & $100^{*}$ & & & & & & 2800 & & 100 & & & & & & 1280 & \\
\hline & 6.0 & $+\quad+$ & $-\quad+$ & & $(+)$ & 0 & 0 & 0 & 0 & $+\quad+$ & + & + & + & + & + & \pm & 0 \\
\hline & 6.2 & ++ & $-\quad+$ & + & + & \pm & 0 & 0 & 0 & $+\quad+$ & + & & + & + & + & $\bar{t}$ & $(+)$ \\
\hline antigen : & 6.4 & ++ & $-\quad+$ & + & + & $(+)$ & 0 & 0 & 0 & + & + & + & + & + & $(+)$ & \pm & 0 \\
\hline Goose & 6.6 & ++ & $-\quad+$ & + & + & + & \pm & 0 & 0 & $+\quad+$ & + & $(+)$ & $\sqrt{ \pm}$ & $0^{*}$ & 0 & 0 & 0 \\
\hline & 6.8 & ++ & -+ & + & + & + & + & 0 & 0 & $(+)(+)$ & $\sqrt{0^{*}}$ & 0 & 0 & 0 & 0 & 0 & 0 \\
\hline & 7.0 & $+\quad+$ & $-t$ & + & & + & + & 0 & 0 & 0 & 0 & 0 & 0 & 0 & 0 & 0 & 0 \\
\hline & 6.0 & $+\quad+$ & -+ & $(+)$ & 0 & 0 & 0 & 0 & 0 & $+\quad+$ & + & + & + & $(+)$ & 0 & 0 & 0 \\
\hline & 6.2 & ++ & $-\quad+$ & + & \pm & 0 & 0 & 0 & 0 & $+\quad+$ & + & & + & + & + & 0 & 0 \\
\hline antigen : & 6.4 & ++ & $-\quad+$ & + & $(+)$ & 0 & 0 & 0 & 0 & $+\quad+$ & + & + & + & + & \pm & 0 & 0 \\
\hline Chick & 6.6 & $+\quad+$ & -+ & + & $(+)$ & \pm & 0 & 0 & 0 & $+\quad+$ & + & $(+)$ & 0 & 0 & () & 0 & 0 \\
\hline & 6.8 & ++ & + & + & $(+)$ & \pm & 0 & 0 & 0 & $(+)(+)$ & \pm & 0 & 0 & 0 & 0 & 0 & 0 \\
\hline & 7.0 & ++ & + & + & + & \pm & 0 & 0 & 0 & $\begin{array}{ll}0 & 0\end{array}$ & 0 & 0 & 0 & 0 & 0 & 0 & 0 \\
\hline & 6.0 & $+\quad+$ & -+ & + & & \pm & 0 & 0 & 0 & + & + & & + & + & + & $(+)$ & $0^{*}$ \\
\hline & 6.2 & $+\quad+$ & -+ & + & + & $(+)$ & \pm & 0 & 0 & $+\quad+$ & + & & + & + & + & + & 0 \\
\hline antigen ; & 6.4 & ++ & -+ & + & + & + & + & 0 & 0 & $+\quad+$ & + & & + & + & + & $(+)$ & 0 \\
\hline $\begin{array}{l}\text { Goose } \\
\text { cell }\end{array}$ & 6.6 & ++ & -+ & + & & + & + & \pm & 0 & $+\quad+$ & + & + & + & $(+)$ & \pm & 0 & 0 \\
\hline & 6.8 &.+ & -+ & + & + & + & + & + & \pm & $+\quad+$ & + & $(+)$ & $0^{*}$ & 0 & 0 & 0 & 0 \\
\hline & 7.0 & $+\quad+$ & -+ & + & + & + & $(+)$ & \pm & 0 & $+\quad+$ & $(+)$ & $0^{*}$ & 0 & 0 & 0 & 0 & 0 \\
\hline & 6.0 & $+\quad+$ & + & + & \pm & 0 & 0 & 0 & 0 & $+\quad+$ & + & & + & $0^{*}$ & 0 & 0 & 0 \\
\hline & 6.2 & $+\quad+$ & + & + & + & \pm & 0 & 0 & 0 & $+\quad+$ & + & + & + & + & $0^{*}$ & 0 & 0 \\
\hline antigen : & 6.4 & ++ & + & + & $(+)$ & $(+)$ & 0 & 0 & 0 & $+\quad+$ & + & $(+)$ & $(+)$ & $0^{*}$ & 0 & 0 & 0 \\
\hline $\begin{array}{l}\text { Chick } \\
\text { cell }\end{array}$ & 6.6 & $+\quad+$ & + & + & + & + & \pm & 0 & 0 & $(+)(+)$ & 0 & 0 & 0 & 0 & 0 & 0 & 0 \\
\hline & 6.8 & ++ & + & + & + & + & \pm & 0 & 0 & $\begin{array}{ll}0^{*} & 0\end{array}$ & 0 & 0 & 0 & 0 & 0 & 0 & 0 \\
\hline & 7.0 & $+\quad+$ & + & + & + & + & \pm & 0 & 0 & $0 \quad 0$ & 0 & 0 & 0 & 0 & 0 & 0 & 0 \\
\hline & 6.0 & $+\quad+$ & + & $(+)$ & \pm & 0 & 0 & 0 & 0 & + & + & + & + & + & \pm & 0 & 0 \\
\hline & 6.2 & $+\quad+$ & + & + & $(+)$ & 0 & 0 & 0 & 0 & + & + & & + & + & + & 0 & 0 \\
\hline antigen : & 6.4 & $+\quad+$ & + & + & + & \pm & 0 & 0 & 0 & + & + & & + & + & + & $(+)$ & $0^{*}$ \\
\hline $\begin{array}{l}\text { Goose } \\
\text { cell }\end{array}$ & 6.6 & $+\quad+$ & + & + & + & + & \pm & 0 & 0 & $+\quad+$ & + & + & $(+)$ & $\sqrt{ \pm}$ & 0 & 0 & 0 \\
\hline & 6.8 & $+\quad+$ & + & + & + & $(+)$ & \pm & 0 & 0 & $\begin{array}{ll}0^{*} & 0^{*}\end{array}$ & \pm & 0 & 0 & 0 & 0 & 0 & 0 \\
\hline & 7.0 & $+\quad+$ & $(+)$ & \pm & 0 & 0 & 0 & 0 & 0 & 0 & 0 & 0 & 0 & 0 & 0 & 0 & 0 \\
\hline & 6.0 & $+(+)$ & \pm & 0 & 0 & 0 & 0 & 0 & 0 & + & $(+)$ & $0^{*}$ & 0 & 0 & 0 & 0 & 0 \\
\hline & 6.2 & $+\quad+$ & + & \pm & 0 & 0 & 0 & 0 & 0 & + & + & + & + & \pm & 0 & 0 & 0 \\
\hline antigen : & 6.4 & $+\quad+$ & + & + & \pm & 0 & 0 & 0 & 0 & $+\quad+$ & $(+)$ & $\sqrt{ \pm}$ & $0^{*}$ & 0 & 0 & 0 & 0 \\
\hline & 6.6 & ++ & + & + & + & \pm & 0 & 0 & 0 & \pm & 0 & 0 & 0 & 0 & 0 & 0 & 0 \\
\hline & 6.8 & + & + & + & + & \pm & 0 & 0 & 0 & 0 & 0 & 0 & 0 & 0 & 0 & 0 & 0 \\
\hline & 7.0 & + & $(+)$ & \pm & 0 & 0 & 0 & 0 & 0 & 0 & 0 & 0 & 0 & 0 & 0 & 0 & 0 \\
\hline
\end{tabular}

JaGAr \#01 strain

I-58 strain

+ : Positive agglutination $(+)$ : Partial agglutination \pm : Trace agglutination

$0^{*}$ : Almost negative 0 : Negative

* Indicates a dilution of antigen. The scale was adjusted for crude antigen because it was prepared into $10 \%$. 
the population of certain strains by plaque selection on chick embryo cells. The shift in optimum $\mathrm{pH}$ during the pro- cesses of plaque purification of Nakayama-NIH strain in chick embryo cells would be attributable to selection from otherwise mixed virus particles having slightly alkaline optimum $\mathrm{pH}$ (6.6) for HA. If this assumption was correct, the ratio between these populations in the original Nakayama-NIH strain may have been maintained as far as the virus was passed through the mouse brain.

The foregoing results strongly indicate the existence of JEV particles differing from each other in their optimum $\mathrm{pH}$ for HA. The difference between both extremes, 6.2 and 7.0, is noticeable. It is most likely that the phenomenon results from a difference in the efficiency of adsorption of viral hemagglutinin onto red cells, but further investigation will be needed.

The authors are grateful for the continuous support of Dr. Masami Kitaoka, chief, Department of Virology and Rickettsiology. Helpful suggestions given by Dr. Akira Oya, chief, Arbovirus Division of the department, as well as the effort paid for the maintenance of old JEV strains by Dr. Takayuki Ogata, Arbovirus Division, are deeply appreciated.

\section{REFERENCES}

Chanock, R. M. and SABin, A. B. (1953): The hemagglutinin of St. Louis encephalitis virus. J. Immunol., 70, 271-316.

CHANOCK, R. M. and SABIN, A. B. (1954a): The hemagglutinin of Western Equine encephalitis virus: Recovery, properties and use for diagnosis. J. Immunol., 73, 337-351.

CHANOCK, R. M. and SABIN, A. B. (1954b) : The hemagglutinin of West Nile virus: Recovery, properties and antigenic relationships. J. Immunol., 73, 352-362.

Clarke, D. H. and Casals, J. (1958): Techniques for hemagglutination and hemagglutination-inhibition with arthropod-borne viruses. Am. J. Trop. Med. \& Hyg., 7, 561-573.

Ohtahara, K., Ogata, M., Okazaki, M. and Sidao, M. (1959): Studies on the epidemic of Japanese B encephalitis of 1958 occurring in Okayama Prefecture and on newly isolated strains, "Okayama 58H" "Okayama 58I". Okayama Igakukai Zasshi, 71, No. 3 Annex, 1-10. (Text in Japanese with English summary)

PORTERFIELD, J. S. (1957): Use of goose cells in hemagglutination tests with arthropod-borne viruses. Nature, 180, 1201.

SABIN, A. B. and BUESCHER, E. L. (1950): Unique physico-chemical properties of Japanese B encephalitis virus hemagglutinin. Proc. Soc. Exptl. Biol. Med., 74, 222-230.

SwEET, B. H. and SABIN, A. B. (1954): Properties and antigenic relationships of hemagglutinins associated with the dengue viruses. J. Immunol., 73, 363-373. 